\title{
Combined bioremediation and enzyme production by Aspergillus sp. in olive mill and winery wastewaters
}

\author{
José Manuel Salgado a , Luís Abrunhosa a , Armando Venâncio a , José Manuel Domínguez b, \\ Isabel Belo ${ }^{\text {a, * }}$ \\ ${ }^{\text {a } C E B-C e n t r e ~ o f ~ B i o l o g i c a l ~ E n g i n e e r i n g, ~ U n i v e r s i t y ~ o f ~ M i n h o, ~ B r a g a, ~ P o r t u g a l ~}$ \\ ${ }^{\mathrm{b}}$ Department of Chemical Engineering, Sciences Faculty, University of Vigo (Campus Ourense), As Lagoas s/n, 32004 Ourense, Spain
}

\section{A R T I C L E I N F O}

\section{Article history:}

Received 19 November 2015

Received in revised form

14 December 2015

Accepted 14 December 2015

Available online xxx

\section{Keywords:}

Vinasses

Olive mill wastewater

Bioremediation

Aspergillus sp.

Lipases

Proteases

Tannases

\begin{abstract}
A B S T R A C T
Olive mill wastewaters (OMW) and vinasses (VS) are effluents produced respectively by olive mills and wineries, both sectors are of great economic importance in Mediterranean countries. These effluents cause a large environmental impact, when not properly processed, due to their high concentration of phenolic compounds, COD and colour. OMW may be treated by biological processes but, in this case, a dilution is necessary, increasing water consumption. The approach here in proposed consists on the bioremediation of OMW and VS by filamentous fungi. In a screening stage, three fungi (Aspergillus ibericus, Aspergillus uvarum, Aspergillus niger) were selected to bioremediate undiluted OMW, two-fold diluted OMW supplemented with nutrients, and a mixture of OMW and VS in the proportion 1:1 (v/ v). Higher reductions of phenolic compounds, colour and COD were achieved mixing both residues; with A. uvarum providing the best results. In addition, the production of enzymes was also evaluated during this bioremediation process, detecting in all cases lipolytic, proteolytic and tannase activities. A. ibericus, A. uvarum and $A$. niger achieved the highest value of lipase $(1253.7 \pm 161.2 \mathrm{U} / \mathrm{L})$, protease $(3700 \pm 124.3 \mathrm{U} / \mathrm{L})$ and tannase $(284.4 \pm 12.1 \mathrm{U} / \mathrm{L})$ activities, respectively. Consequently, this process is an interesting alternative to traditional processes to manage these residues, providing simultaneously high economic products, which can be employed in the same industries.
\end{abstract}

() 2016 Published by Elsevier Ltd.

\section{Introduction}

Liquid wastes from agro-industrial processes like wineries and olive oil industries are sources of local water pollution. Generally, these industries are nearby and generate their wastes at the same time of the year. For this reason, a common process to treat both wastes is of great interest. Vinasses (VS) and olive mill wastewaters (OMW) are the main liquid wastes generated in wineries and olive mills, respectively. These effluents are harmful to sewage treatment plants due to the large amounts of organic and suspended matter (Rytwo et al., 2013).

VS are liquid wastes generated by the distillation process of lees and low quality wines. Like other winery wastes, VS present acidic $\mathrm{pH}$ values, high biochemical oxygen demand (BOD) and chemical oxygen demand (COD). These wastes contain dead microorganisms and other compounds of wine (e.g. phenols, acids, carbohydrates,

\footnotetext{
* Corresponding author.

E-mail address: ibelo@deb.uminho.pt (I. Belo).
}

mineral salts) (Salgado et al., 2010). Commonly, VS are released to surface waters causing significant environmental problems (Beltrán et al., 1999). The amount of VS generated is 8-15 times greater than the ethanol production (Strong, 2009). In addition, the VS are produced in large quantities in a short season, making its treatment a harder challenge (Vlyssides et al., 2010). In the past few years, multiple applications have been investigated to manage their proper treatment. Among other applications, VS have been proposed as a nutritional supplement for microorganism growth (Salgado et al., 2009), for the production of protein-rich fungal biomass (Nitayavardhana and Khanal, 2010) or as a co-product in grape marc composting (Paradelo et al., 2010).

OMW are stable emulsions composed of water, olive pulp remains and residual oil (Lanciotti et al., 2005). Due to their high content on phenolic compounds (PC), COD and long-chain fatty acids, OMW are toxic to microorganisms and plants, and cannot be directly disposed into the environment (Paraskeva and Diamadopoulos, 2006; Sierra et al., 2007; Iamarino et al., 2009; Zirehpour et al., 2014). A common use of OMW is as soil 
amendment, but it can cause phytotoxic problems and change physicochemical characteristics of soil (Mekki et al., 2007). To meet the environmental standards, aerobic and anaerobic biological processes, including anaerobic co-digestion with other effluents and composting, are predominantly used to treat OMW (Paraskeva and Diamadopoulos, 2006). Bioremediation is environmentally friendly and cost competitive in comparison with chemical decomposition (España-Gamboa et al., 2011). This treatment can reduce COD and phenolic content, thus facilitating further management before its disposal (Ntougias et al., 2012). Nevertheless, phenols can act as inhibitors of many microorganisms, when present at low concentrations, and may reduce the performance of biological treatments. Therefore, in many cases, it is necessary to dilute OMW in order to reduce its toxicity to microorganisms, increasing water consumption (Öngen et al., 2007; Mann et al., 2010; Jarboui et al., 2013; Lakhtar et al., 2010).

The mixture of OMW with other agro-industrial effluents, which have lower pollutant load, may be a way to improve biological treatment performances. With this approach, initial phenolic content and COD can be reduced, avoiding the inhibition of microorganisms without using water. For example, cheese whey's addition to OMW in a proportion of $90 / 10(\mathrm{v} / \mathrm{v})$ was necessary to achieve the highest colour and phenolic reduction during the biological treatment of OMW with Lactobacillus paracasei (Aouidi et al., 2009).

Aerobic treatments for OMW detoxification can be performed by bacteria and fungi (Aouidi et al., 2009; Gonçalves et al., 2009; Mann et al., 2010). Three types of fungi are commonly used: white rot fungi, Aspergillus spp. and several different yeasts (McNamara et al., 2008). Among the Aspergillus genera, Aspergillus niger and Aspergillus terreus have been the most studied species to reduce PC, COD and colour of OMW (Garcia-Garcia et al., 2000; Garrido-Hoyos et al., 2002). A. niger belongs to the so called black aspergilli group, which include presently 19 accepted taxa (Samson et al., 2007). New species belonging to this group have been isolated from grape berries as Aspergillus uvarum and Aspergillus ibericus (Perrone et al., 2008; Serra et al., 2006). Production of enzymes in OMW and their detoxification by A. ibericus have already been tested (Abrunhosa et al., 2012), but A. uvarum has not been studied yet.

The aim of the present work was to select novel strains of Aspergillus spp., which could decolourise as well as improve the bioremediation of OMW, and study their suitability to treat OMW and VS mixtures while producing enzymes.

\section{Materials and methods}

\subsection{Characterisation of effluents}

The OMW were collected from olive mill (Region of Trás-osMontes) and VS were collected from winery (Region of Minho) in 2012. Both effluents were separately homogenized and stored at $-20{ }^{\circ} \mathrm{C}$ until use.

Total nitrogen (TN) was determined by the test kit Hach Lange LCK 338. For COD determination, the test kit Hach Lange LCK914 was used according to the manufacturer method. Total organic carbon (TOC) in liquid residues was quantified by the test kit Hach Lange LCK 387. Reducing sugars were determined by the dinitrosalicylic acid (DNS) method, and protein was analysed according to the Bradford method (Bradford, 1976). Total phenols were assessed by the Folin-Ciocalteau method (Commission Regulation (EEC) No. 2676/90), using caffeic acid as standard. Total solids were analysed by oven-dried to constant weight at $105^{\circ} \mathrm{C}$.

\subsection{Screening of fungi for OMW bioremediation on agar plates}

Table 1 shows the strains of Aspergillus assayed in this work, all of them supplied by MUM culture collection (University of Minho, Braga, Portugal). Fungi were cultivated to observe mycelium growth and decolourisation of OMW in agar media formulated with undiluted OMW, OMW diluted in the proportion 1:1 and 1:10 $(\mathrm{v} / \mathrm{v})$ with a nutrient supplemented medium $\left(3 \mathrm{~g} / \mathrm{L} \mathrm{NaNO}_{3}, 1 \mathrm{~g} / \mathrm{L}\right.$ $\mathrm{K}_{2} \mathrm{HPO}_{4}, 0.5 \mathrm{~g} / \mathrm{L} \mathrm{KCl}, 0.5 \mathrm{~g} / \mathrm{L} \mathrm{MgSO}_{4} \cdot 7 \mathrm{H}_{2} \mathrm{O}, 0.5 \mathrm{~g} / \mathrm{L} \mathrm{CaCl}_{2} \cdot 2 \mathrm{H}_{2} \mathrm{O}, 1 \mathrm{~mL} /$ $\mathrm{L}$ metal solution $\left(10 \mathrm{~g} / \mathrm{L} \mathrm{ZnSO}_{4} \cdot 7 \mathrm{H}_{2} \mathrm{O}, \mathrm{CuSO}_{4} \cdot 5 \mathrm{H}_{2} \mathrm{O}, \mathrm{FeSO}_{4} \cdot 7 \mathrm{H}_{2} \mathrm{O}\right)$ ) or diluted $1: 1$ and $1: 3(\mathrm{v} / \mathrm{v})$ with VS. Fungi were pre-incubated on malt extract agar (MEA) (2\% malt extract, $2 \%$ glucose, $0.1 \%$ peptone and $2 \%$ agar) plates at $25{ }^{\circ} \mathrm{C}$ and stored at $4{ }^{\circ} \mathrm{C}$ before inoculation on OMW agar plates. Inoculum was placed into the centre of the corresponding dishes, the growth and the halo of OMW decolourisation were followed during five days by measuring diameters of mycelium growth and decolourisation halos by visual inspection.

\subsection{Bioremediation process by submerged fermentation}

Submerged fermentations were performed in $250 \mathrm{~mL}$ Erlenmeyer flasks containing $100 \mathrm{~mL}$ of culture medium. The three media studied were 100\% OMW without supplementation; OMW:nutrient supplementation medium $(1: 1, \mathrm{v} / \mathrm{v})$ and OMW:VS $(1: 1, \mathrm{v} / \mathrm{v})$. Flasks with media were sterilised during $15 \mathrm{~min}$ at $121^{\circ} \mathrm{C}$. Spores stored at $4{ }^{\circ} \mathrm{C}$ in slant tubes were suspended in a solution ( $0.01 \%$ peptone and $0.01 \%$ Tween 80 ) by strong agitation. Once spores were suspended, all media were inoculated with $2 \mathrm{~mL}$ of spores' suspension $\left(10^{7}\right.$ spores/mL, counted with Neubauer chamber). The flasks were then incubated at $25{ }^{\circ} \mathrm{C}$ without agitation. Samples were collected during fermentation. All experiments were performed in duplicate.

\subsection{Analytical methods}

Decolourisation of media in submerged fermentations was determined by measuring absorbance at wavelengths of 395 and $525 \mathrm{~nm}$. The biomass dry weight was determined at the end of fermentation after filtration using common laboratory filters (Whatman $\mathrm{N}^{\circ} 1$ ) followed by drying at $100{ }^{\circ} \mathrm{C}$. COD and total phenols were measured by the methods previously described. Statistical analyses were performed using Statistica 5.0 software.

Protease activity was quantified by a spectrophotometric method (Charney and Tomarelli, 1947), which is based on the reaction of $0.5 \mathrm{~mL}$ of SSF extracts with $0.5 \mathrm{~mL}$ of $0.5 \%(\mathrm{w} / \mathrm{v}$ ) azocasein in acetate buffer $50 \mathrm{mM}(\mathrm{pH} \mathrm{5})$ at $37{ }^{\circ} \mathrm{C}$ during $40 \mathrm{~min}$. After incubation, $10 \%(\mathrm{w} / \mathrm{v})$ trichloroacetic acid was added to precipitate residual protein not hydrolysed by the proteolytic enzymes. The sample was centrifuged ( $3000 \mathrm{~g}, 5 \mathrm{~min}$ ) and a solution of potassium hydroxide $5 \mathrm{~N}$ was added to the supernatant, producing a pinkyorange colour. The intensity of this coloration was measured at a wavelength of $428 \mathrm{~nm}$. The blank was performed under the same conditions, but adding trichloroacetic acid before incubation. One unit of proteolytic activity was defined as the amount of enzyme that produced an increase of 0.01 in absorbance relatively to the blank per minute, under the assay conditions.

Lipolytic activity was determined by spectrophotometric method, which was carried out using $p$-nitrophenyl-butyrate ( $p$ $\mathrm{NPB}$ ) in sodium acetate buffer $50 \mathrm{mM}(\mathrm{pH} 5.6)$ as substrate. The reaction mixture was incubated at $37{ }^{\circ} \mathrm{C}$ for $15 \mathrm{~min}$ and was stopped by adding acetone (Gomes et al., 2011). The absorbance was measured at a wavelength at $405 \mathrm{~nm}$. One unit of activity was defined as the amount of enzyme required to release $1 \mu \mathrm{mol}$ of $p$ nitrophenol per minute, under the assay conditions.

Tannase activity was analysed by spectrophotometric method 
Table 1

Evaluation of media decolourisation on agar plates.

\begin{tabular}{|c|c|c|c|c|c|c|}
\hline Strain & Code & OMW 10\% & OMW 50\% & OMW 100\% & $\begin{array}{l}\text { OMW:VS } \\
(1: 1)\end{array}$ & $\begin{array}{l}\text { OMW:VS } \\
(3: 1)\end{array}$ \\
\hline A. niger & MUM 03.58 & ++ & ++ & ++ & +++ & +++ \\
\hline A. niger & MUM 92.13 & ++ & ++ & ++ & +++ & +++ \\
\hline A. niger & 01 UAs83 & - & +++ & +++ & +++ & +++ \\
\hline A. niger & 01UAs181 & - & +++ & +++ & +++ & +++ \\
\hline A. niger & 01UAs107 & ++ & +++ & +++ & +++ & +++ \\
\hline A. foetidus & 01UAs162 & ++ & +++ & ++ & +++ & +++ \\
\hline A. ibericus & 03UAs268 & +++ & +++ & +++ & +++ & +++ \\
\hline A. ibericus & MUM 03.49 & ++ & +++ & +++ & +++ & +++ \\
\hline A. ibericus & 03UAs91 & +++ & +++ & +++ & +++ & +++ \\
\hline A. ibericus & 03 UAs113 & - & +++ & +++ & +++ & +++ \\
\hline A. uvarum & 01UAs128 & ++ & +++ & ++ & +++ & +++ \\
\hline
\end{tabular}

Data collected after 5 days of growth, except the mixture of OMW:VS that corresponds to the 4th day of growth.

+ positive, ring $<2 \mathrm{~cm}$.

++ positive, ring $>2 \mathrm{~cm}$.

+++ positive, ring $>4 \mathrm{~cm}$.

- without ring.

based on the formation of a chromogen between gallic acid and rhodanine (Sharma et al., 1999). One unit of activity was defined as a micromole of gallic acid released per minute, under the assay conditions $\left(30^{\circ} \mathrm{C}, 10 \mathrm{~min}\right)$.

\section{Results and discussion}

\subsection{Screening of fungi}

Three types of microorganisms (white rot fungi, Aspergillus spp. and yeasts) have been mainly used in several studies to examine the ability of fungi to bioremediate OMW (McNamara et al., 2008), although the use of white rot fungi is more common than the use of Aspergillus. However, it was observed that some species of Aspergillus are also able to reduce the COD and PC of OMW (Aissam et al., 2007; Öngen et al., 2007). Aissam et al. (2007) evaluated the reduction of PC and COD with two yeasts (Candida boidinii and Geotrichum candidum) and two fungi (Penicillium sp. and A. niger). They observed that $A$. niger removed more COD and PC than the others microorganisms. In addition, Aspergillus spp. can biodegrade products of OMW in shorter cultivation periods than white rot fungi (Öngen et al., 2007).

Consequently, the growth of several Aspergillus strains belonging to the $A$. niger group was tested on agar plates to observe their ability to decolourise different concentrations of OMW and mixtures of OMW with VS. Table 1 shows that all strains were able to decolourise the plates with the different OMW media formulations in five days, with the exception of A. niger 01UAs83, A. niger 01UAs181 and $A$. ibericus 03UAs113 that did not grow on medium with $10 \%$ OMW, probably due to the low availability of carbon sources. The decolourisation of OMW may be due to the reduction of polyphenols which cause the dark colour of this waste. The OMW content on polyphenols depends on the age, type of olive and technology used (Yesilada et al., 1999). Undiluted OMW showed to be suitable for fungal growth; however, faster growth in media with diluted OMW was observed. The same conclusion was withdrawn in agar plates with mixtures of OMW and VS, where the maximum decolourisation and growth were achieved in four days. Öngen et al. (2007) reported the need to supplement OMW with nutrients, as yeast extract and minerals, to enhance microbial growth. Thus, the use of VS may replace the need to OMW supplementation with other nutrient sources, reducing the cost of process. Among all the fungi studied, A. niger MUM03.58, A. uvarum 01UAs128 and A. ibericus MUM 03.49 were selected to test OMW biodegradation in submerged fermentation.

\subsection{Effect of VS addition on the biodegradation of OMW}

To improve the process of bioremediation of OMW by fungi, different mixtures of OMW and VS were evaluated. Nitrogen, TOC, COD, reducing sugars, protein, lipids, total phenols and total solids were analysed in order to characterize these effluents and to compare them with data from the literature (Table 2). COD is an important parameter that measures the pollution load of effluents, being related with the organic load. In OMW, the organic load can be 100-150 times higher than in domestic wastewaters (Khatib et al., 2009). As shown in Table 2, in the effluents of this work, the COD in OMW was higher than in VS. However, observing not only those data reported in literature but also those determined in this work, it can be inferred that the limits can vary widely depending on the dilution effects caused by washing operations. On the contrary, the total nitrogen content in OMW was lower than in VS, since the latter contains dead cells of microorganisms, mainly yeasts and lactic acid bacteria, which are a source of nitrogen. For this reason, VS were already studied as a source of nutrients in different biotechnological processes (Salgado et al., 2009). The PC in OMW were higher than in VS. High levels of PC can inhibit microbial growth and can show phytotoxic effects. More than 30 different PC have been observed in OMW (McNamara et al., 2008). These levels of PC prevent the use of non-treated OMW for irrigation purposes in agricultural practices (McNamara et al., 2008).

Figs. 1-3 show the variations of $\mathrm{pH}$, percentage of decolourisation and PC over time, during the biological treatment of undiluted and diluted OMW and the mixture OMW:VS (1:1) with the three selected fungi.

Fig. 1a-c displays the biodegradation of undiluted OMW, twofold diluted OMW and OMW:VS $(1: 1, \mathrm{v} / \mathrm{v})$ by $A$. niger. The $\mathrm{pH}$ dropped from 5.2 to 4.6 after twelve days of fermentation in undiluted OMW, this behaviour was similar in the mixtures of OMW with VS; however, in two-fold diluted OMW medium the decrease was higher. A decrease of $\mathrm{pH}$ was also observed during cofermentation of OMW with cheese whey (Aouidi et al., 2009).

Decolourisation of OMW were analysed by measuring the absorbance at $395 \mathrm{~nm}$ and $525 \mathrm{~nm}$ over time. Table 3 shows the absorbance before and after the biological treatment. A. ibericus showed a higher decolourisation of undiluted OMW than the other fungi, achieving a colour reduction of $42.8 \%$ (at $525 \mathrm{~nm}$ ) and 33.8\% (at $395 \mathrm{~nm}$ ) after 12 days. A. niger reduced moderately the colour of undiluted OMW, 33\% (at $525 \mathrm{~nm}$ ) and 25\% (at $395 \mathrm{~nm}$ ). A. uvarum exhibited no decolourisation of undiluted OMW, although it has been observed fungal growth in this medium. In a similar work, 
Table 2

Main characteristics of effluents from wineries and olive oil industries.

\begin{tabular}{|c|c|c|c|c|c|c|c|c|}
\hline \multirow[t]{2}{*}{ Reference } & \multicolumn{4}{|l|}{ VS } & \multicolumn{4}{|l|}{ OMW } \\
\hline & $*$ & a & b & c & $*$ & $\mathrm{~d}$ & e & $\mathrm{f}$ \\
\hline Nitrogen (mg/L) & $218.67 \pm 35.27$ & 1354 & 740 & 1341 & $5.2 \pm 0.2$ & 250 & 3.4 & n.d. \\
\hline TOC $(g / L)$ & $3.53 \pm 0.02$ & 7.36 & 10.86 & n.d & $21.4 \pm 1.2$ & n.d & 15.3 & n.d. \\
\hline $\operatorname{COD}(\mathrm{g} / \mathrm{L})$ & $48.07 \pm 1.43$ & 21.72 & 27.5 & 121 & $122.9 \pm 0.42$ & 20 & 97 & 43.35 \\
\hline Reducing sugars (g/L) & $0.68 \pm 0.01$ & n.d. & n.d. & n.d. & $12.7 \pm 1.3$ & 7.51 & 11.5 & n.d. \\
\hline Protein $(\mathrm{g} / \mathrm{L})$ & $0.31 \pm 0.08$ & n.d. & 2.75 & n.d. & $0.04 \pm 0.01$ & n.d & n.d. & n.d. \\
\hline Lipids $(\mathrm{g} / \mathrm{L})$ & - & n.d. & 0.25 & n.d. & $4.1 \pm 0.42$ & n.d. & 3.5 & n.d. \\
\hline Total phenols (g/L) & $0.54 \pm 0.03$ & 0.74 & n.d. & n.d. & $5.91 \pm 0.09$ & 1.48 & 2.7 & 2.84 \\
\hline Total solids $(\mathrm{g} / \mathrm{L})$ & $22.24 \pm 0.09$ & 0.75 & 36.6 & 10.27 & $15.48 \pm 0.54$ & 19.7 & 58 & 55.59 \\
\hline
\end{tabular}

OMW: olive mill wastewater; TOC: total organic carbon; COD: chemical oxygen demand.

* Characteristics of effluents in current work (Salgado et al., 2014).

a: Beltrán et al., 1999, b: Vlyssides et al., 2010; c: España-Gamboa et al., 2012; d: Aouidi et al., 2009; e: Abrunhosa et al., 2012 ; f: Garrido-Hoyos et al., 2002.
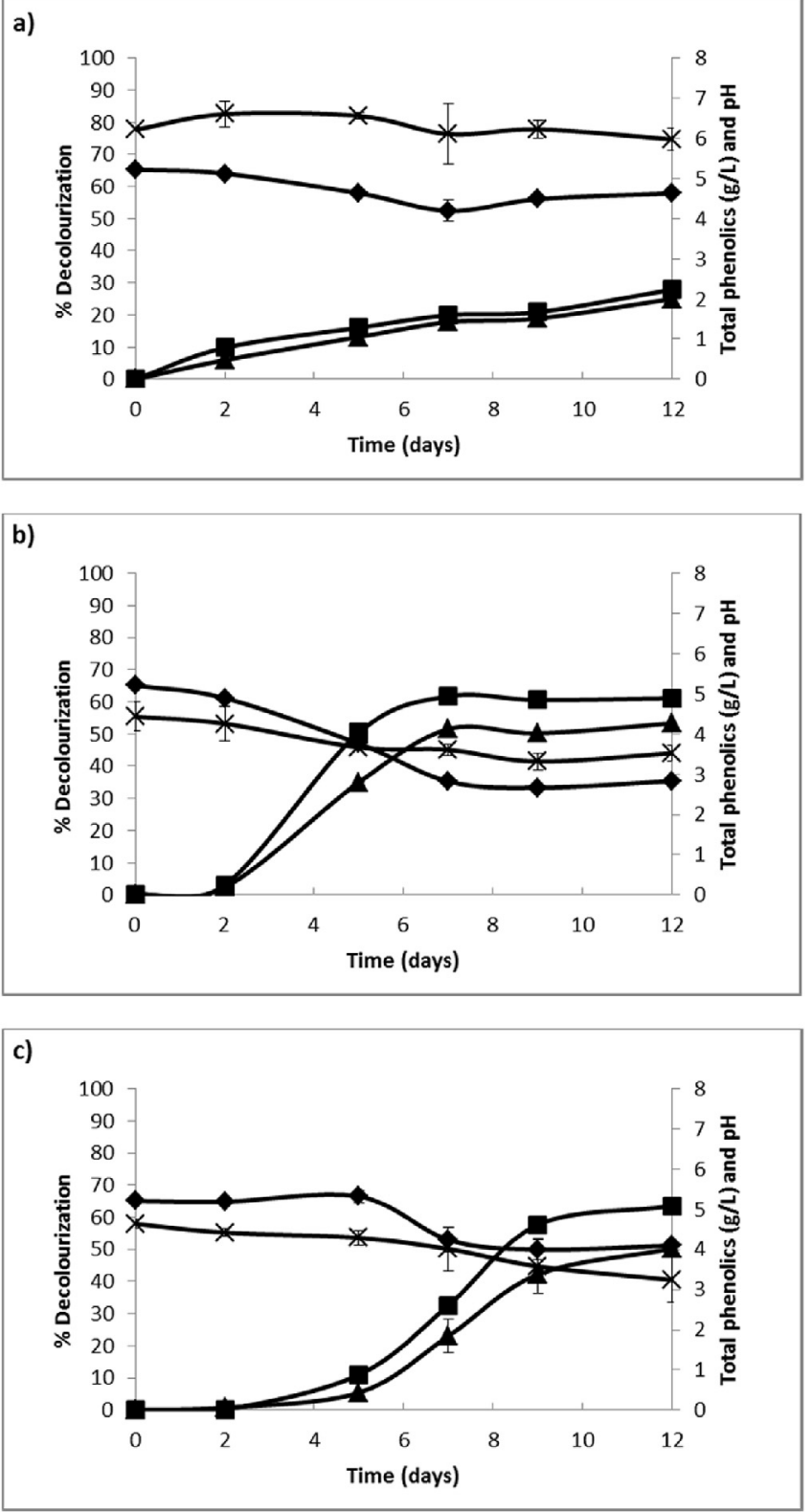

Fig. 1. Bioremediation of (a) undiluted OMW, (b) two-fold diluted OMW supplemented with nutrients, and (c) OMW:VS (1:1, v/v) with A. niger MUM 03.58. ( $\times$ ) PC, $(\bullet) \mathrm{pH}$, and \% decolourisation measured by reduction of absorbance at $395 \mathrm{~nm}(\boldsymbol{\Delta})$ and $525 \mathrm{~nm}(\boldsymbol{\square})$.

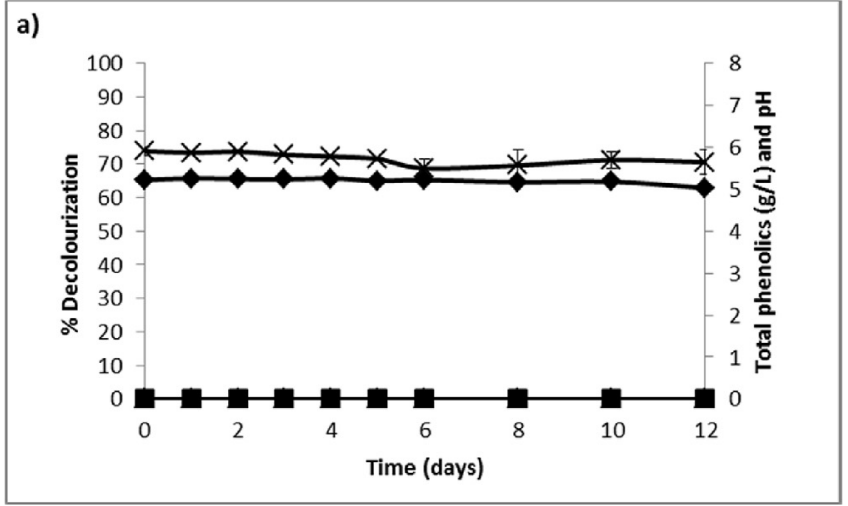

b)

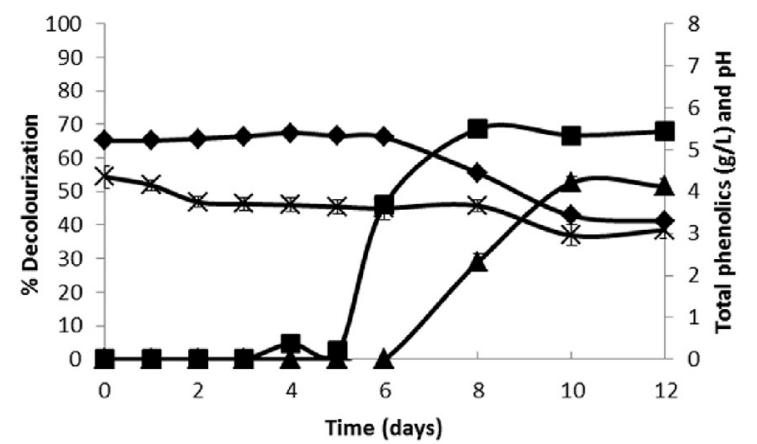

c)

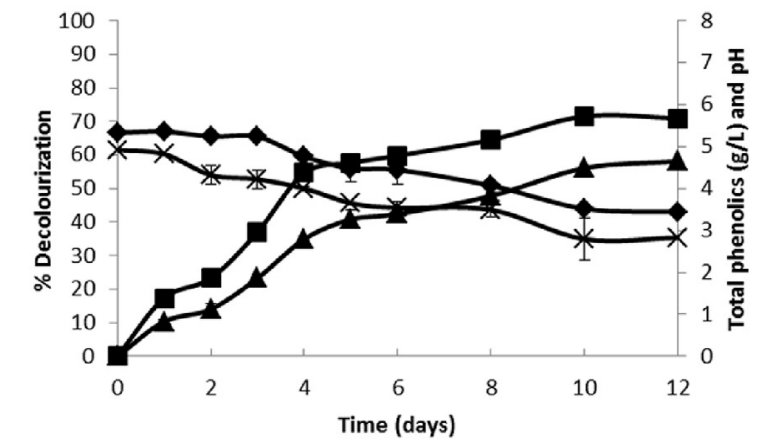

Fig. 2. Bioremediation of (a) undiluted OMW, (b) two-fold diluted OMW supplemented with nutrients, and (c) OMW:VS (1:1, v/v) with A. uvarum 01UAs128. (X) PC, $(\bullet) \mathrm{pH}$, and \% decolourisation measured by reduction of absorbance at $395 \mathrm{~nm}(\boldsymbol{\Delta})$ and $525 \mathrm{~nm}(\boldsymbol{\square})$ 

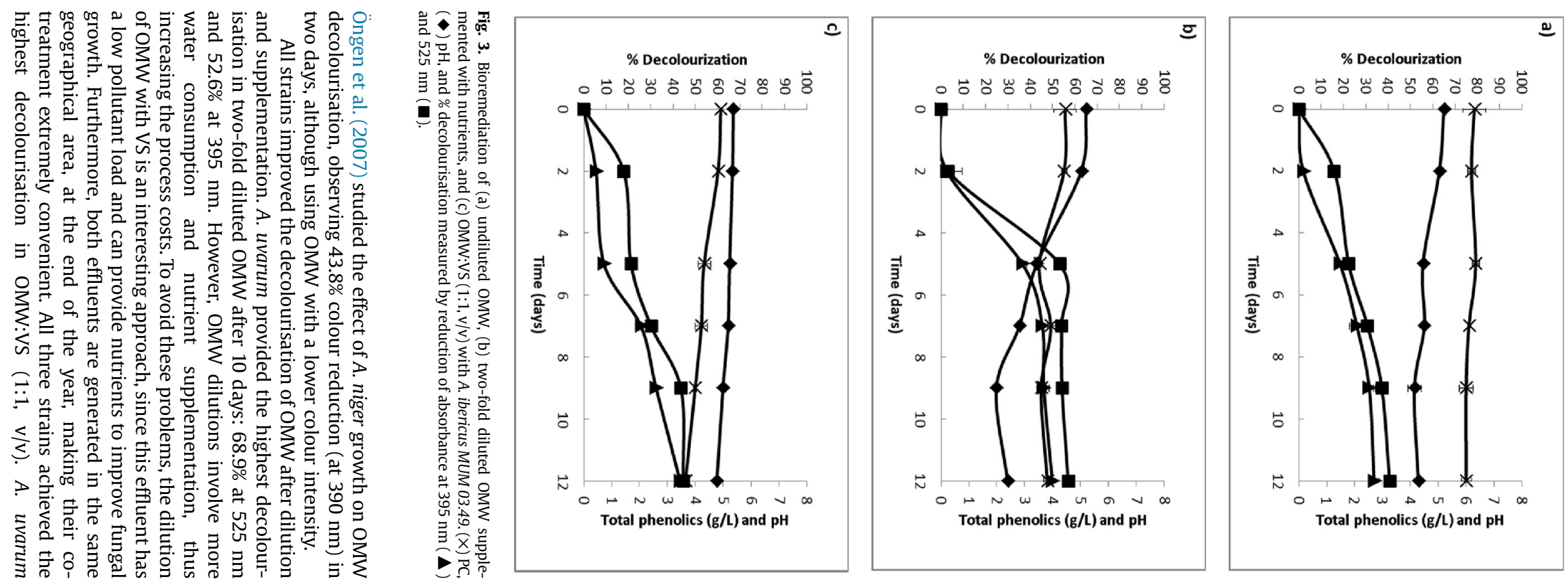

Table 3

Biomass, COD, colour and total phenols before and after biological treatment of OMW.

\begin{tabular}{|c|c|c|c|c|c|c|c|c|c|c|c|c|c|c|c|c|}
\hline \multirow[t]{2}{*}{ Fungi } & \multicolumn{6}{|l|}{ OMW (100\%) } & \multicolumn{5}{|l|}{ OMW (50\%) } & \multicolumn{5}{|l|}{ OMW:VS (1:1) } \\
\hline & Biological treatment & Biomass $(\mathrm{g} / \mathrm{L})$ & $\operatorname{COD}(\mathrm{g} / \mathrm{L})$ & $\mathrm{C}\left(\mathrm{Abs}_{395}\right)$ & $\mathrm{C}\left(\mathrm{Abs}_{525}\right)$ & $\mathrm{TP}(\mathrm{g} / \mathrm{L})$ & Biomass $(\mathrm{g} / \mathrm{L})$ & $\operatorname{COD}(\mathrm{g} / \mathrm{L})$ & $\mathrm{C}\left(\mathrm{Abs}_{395}\right)$ & $\mathrm{C}\left(\mathrm{Abs}_{525}\right)$ & $\mathrm{TP}(\mathrm{g} / \mathrm{L})$ & Biomass $(\mathrm{g} / \mathrm{L})$ & $\operatorname{COD}(\mathrm{g} / \mathrm{L})$ & $\mathrm{C}\left(\mathrm{Abs}_{395}\right)$ & $\mathrm{C}\left(\mathrm{Abs}_{525}\right)$ & $\mathrm{TP}(\mathrm{g} / \mathrm{L})$ \\
\hline \multirow[t]{3}{*}{ A. ibericus } & Before & & $129.9 \pm 0.7$ & $31.1 \pm 0.4$ & $13.9 \pm 0.5$ & $6.3 \pm 0.1$ & & $79.2 \pm 5.1$ & $14.8 \pm 0.6$ & $6.8 \pm 0.4$ & $4.5 \pm 0.4$ & & $92.6 \pm 1.1$ & $20.6 \pm 0.1$ & $8.85 \pm 0.1$ & $4.9 \pm 0.1$ \\
\hline & After & $30.71 \pm 0.33$ & $115.8 \pm 0.4$ & $20.6 \pm 0.9$ & $7.9 \pm 0.4$ & $6.0 \pm 0.2$ & $18.59 \pm 0.21$ & $33.1 \pm 2.7$ & $7.4 \pm 0.1$ & $2.9 \pm 0.1$ & $3.8 \pm 0.1$ & $17.84 \pm 0.15$ & $60.8 \pm 0.8$ & $11.7 \pm 0.2$ & $4.9 \pm 0.1$ & $3.6 \pm 0.2$ \\
\hline & $\%$ red. & & $10.9 \pm 0.5$ & $33.8 \pm 2.2$ & $42.8 \pm 0.5$ & $4.6 \pm 0.4$ & & $58.2 \pm 2.7$ & $50 \pm 1.4$ & $57.1 \pm 1.8$ & $14.2 \pm 5.1$ & & $34.3 \pm 0.8$ & $43.2 \pm 0.5$ & $44.6 \pm 0.6$ & $26.5 \pm 0.9$ \\
\hline \multirow[t]{3}{*}{ A. uvarum } & Before & & $122.9 \pm 0.4$ & $27.4 \pm 1.5$ & $11.3 \pm 0.4$ & $5.9 \pm 0.1$ & & $79.6 \pm 1.4$ & $15.9 \pm 1.1$ & $7.2 \pm 0.9$ & $4.4 \pm 0.2$ & & $91.1 \pm 7.7$ & $20.6 \pm 0.2$ & $8.8 \pm 0.4$ & $4.9 \pm 0.1$ \\
\hline & After & $24.60 \pm 0.43$ & $121.2 \pm 0.3$ & $34.9 \pm 0.7$ & $17.4 \pm 1.1$ & $5.7 \pm 0.2$ & $18.93 \pm 0.34$ & $35.2 \pm 0.8$ & $7.5 \pm 0.3$ & $2.2 \pm 0.1$ & $2.9 \pm 0.2$ & $27.43 \pm 0.03$ & $31.8 \pm 2.9$ & $9.1 \pm 0.1$ & $2.5 \pm 0.1$ & $2.8 \pm 0.3$ \\
\hline & $\%$ red. & & $1.4 \pm 0.3$ & $0.0 \pm 0.0$ & $0.0 \pm 0.0$ & $3.6 \pm 1.8$ & & $55.8 \pm 0.8$ & $52.6 \pm 1.6$ & $68.9 \pm 3.6$ & $32.2 \pm 1.6$ & & $65.1 \pm 3.1$ & $56.1 \pm 0.6$ & $71.6 \pm 1.5$ & $43.3 \pm 0.8$ \\
\hline \multirow[t]{3}{*}{ A. niger } & Before & & $125.7 \pm 4.4$ & $33.6 \pm 0.1$ & $16.2 \pm 0.5$ & $6.2 \pm 0.1$ & & $77.2 \pm 4.8$ & $14.8 \pm 0.4$ & $6.6 \pm 0.3$ & $4.4 \pm 0.4$ & & $89.5 \pm 5.5$ & $19.1 \pm 0.9$ & $7.1 \pm 0.6$ & $4.6 \pm 0.1$ \\
\hline & After & $28.95 \pm 0.13$ & $116.8 \pm 3.2$ & $25.2 \pm 1.7$ & $10.8 \pm 1.1$ & $5.9 \pm 0.3$ & $20.34 \pm 0.54$ & $39.8 \pm 3.2$ & $6.9 \pm 0.1$ & $2.6 \pm 0.1$ & $3.5 \pm 0.2$ & $28.97 \pm 0.35$ & $29.6 \pm 2.1$ & $9.5 \pm 0.2$ & $2.6 \pm 0.1$ & $3.2 \pm 0.3$ \\
\hline & $\%$ red. & & $7 \pm 3.2$ & $25 \pm 5.1$ & $33 \pm 9.1$ & $3.9 \pm 5.4$ & & $48.4 \pm 3.2$ & $53.4 \pm 2.1$ & $61.1 \pm 1.4$ & $20.5 \pm 2$ & & $66.9 \pm 2$ & $50.4 \pm 1.3$ & $63.7 \pm 1.4$ & $30.2 \pm 2$ \\
\hline
\end{tabular}

OMW: olive mill wastewater: VS: vinasses: COD: chemical oxygen demand; C: colour; TP: total phenols; red: reduction. 
accounted for the highest decolourisation $(71.6 \%$ at $525 \mathrm{~nm}$ and 56.1 at $395 \mathrm{~nm}$ ) after 10 days of incubation.

Fungi show better decolourisation and biodegradation activities at acidic or neutral pH (Khan and Fulekar, 2013). The colour and phenols can be reduced by acidic treatments (Hamdi, 1993), thus a decrease of $\mathrm{pH}$ could cause a reduction of colour. To evaluate the effect of $\mathrm{pH}$ on the colour removal of OMW and OMW:VS $(1: 1, \mathrm{v} / \mathrm{v})$, the absorbances at 395 and $525 \mathrm{~nm}$ were measured at different values of $\mathrm{pH}$ (Fig. $4 \mathrm{a}-\mathrm{b}$ ). In both cases, it was observed a reduction of colour about 25\% at pH 4. Hamdi (1993) observed that acidic treatment of OMW only removed the polyphenols responsible for black colour.

Concerning phenols the lower removal was observed when undiluted OMW were assayed as basal media, in spite of the higher values achieved with $A$. ibericus (17.6\% reduction). Nonetheless, the high concentration of initial phenols quantified in the OMW $(>7 \mathrm{~g} /$ L) may have hindered the reduction of the PC. D'Annibale et al. (2004) observed a great improvement in biological reduction of phenolic compounds in OMW with a lower initial phenolic content. In two-fold diluted OMW, dephenolization improved with all fungi tested. A. uvarum obtained the maximum percentage of dephenolisation (32.2\%) after 10 days. In the mixture OMW:VS (1:1, v/v), even higher reductions were observed. A. uvarum reached a dephenolisation of $43.3 \%$ after 10 days (Table 3). Thereby, diluting OMW with VS rather than with supplemented medium improved further the reduction of phenolic compounds. Öngen et al. (2007) achieved similar results in two-fold diluted OMW without any supplements. Using Aspergillus tubingensis, they achieved a $34.6 \%$
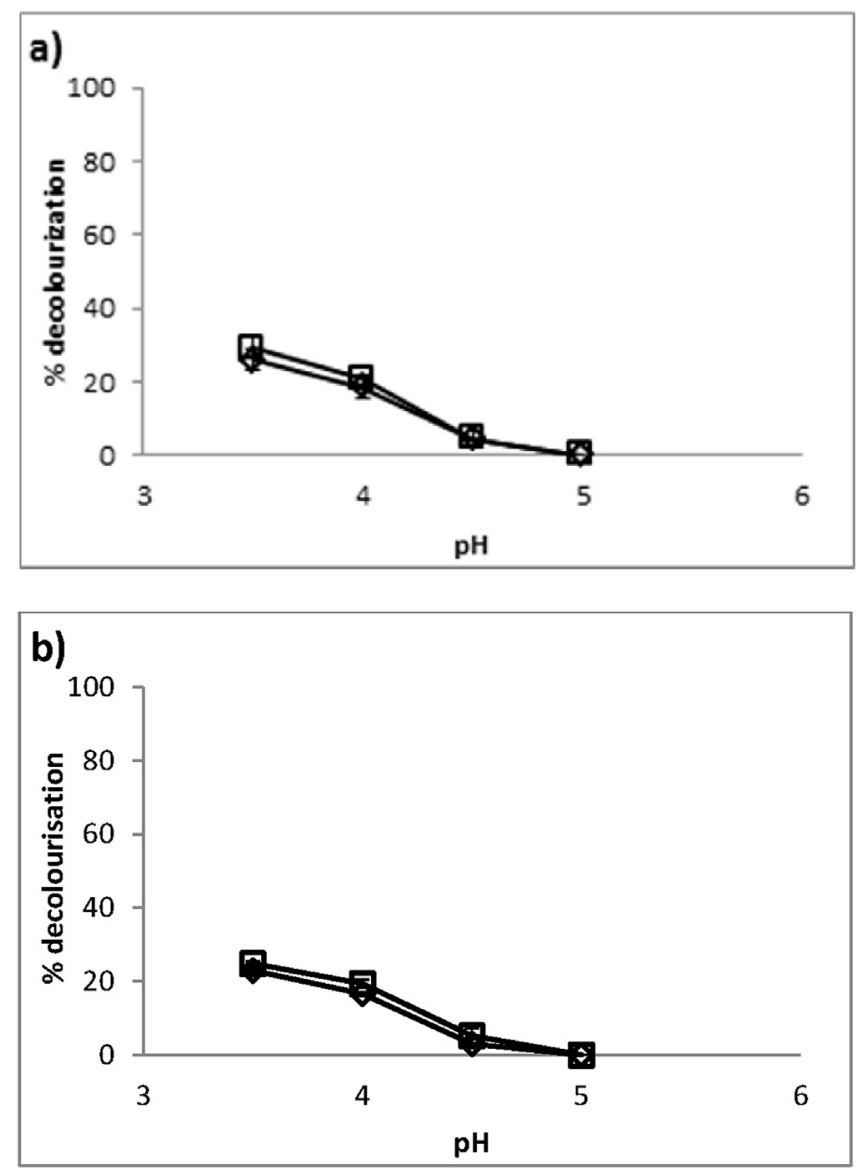

Fig. 4. Effect of $\mathrm{pH}$ in decolourisation of OMW (a) and OMW:VS (1:1, v/v) (b). Absorbance at $395 \mathrm{~nm}(\square)$, absorbance at $525 \mathrm{~nm}(\diamond)$. phenolic compounds removal; however, as stated before, the initial phenolic content of OMW was lower. In mixtures of OMW:cheese whey $(1: 1, v / v)$, biological reduction of phenolic compounds was 28.9\% (Aouidi et al., 2009). Dephenolisation can also be achieved with adsorbent matrices as activated carbon, resins and zeolites. Some of them have even showed best results than fungal treatments when they were used at concentrations greater than $50 \mathrm{~g} / \mathrm{L}$ (Padovani et al., 2013). However, the use of such matrices increases the cost of the process.

COD was measured before and after fungal treatment (Table 3 ). In undiluted OMW, the percentage of COD reduction was low. The best result was achieved with $A$. ibericus which removed $10.9 \%$ of initial COD. Two-fold diluted OMW, improved the removal of COD. $A$. ibericus and A. uvarum showed a similar percentage as COD reduction $58.2 \%$ and $55.8 \%$, respectively. Once more, the mixture of OMW with VS improved the bioremediation process. A. uvarum and A. niger achieved reductions of $65.1 \%$ and $66.9 \%$ of the initial COD. In physicochemical treatment with granular activated carbon, reduction of COD of 69.7\% was also achieved (Padovani et al., 2013). In mixture of OMW with cheese whey, L. paracasei reduced initial COD by $16 \%$ (Aouidi et al., 2009). Biological treatment by Phanerochaete chrysosporium allowed to reduce COD of OMW with an initial value of $80 \mathrm{~g} / \mathrm{L}$ in about 75\% (Sayadi and Ellouz, 1995). Aissam et al. (2007) also evaluated several fungi to bioremediate OMW and observed that $A$. niger reduced $80 \%$ of COD in OMW with an initial content of $82 \mathrm{~g} / \mathrm{L}$, after an adaptation phase.

\subsection{Enzymes production in the biodegradation processes}

In addition to assessing the bioremediation of OMW and VS, enzymes production after fermentation with Aspergillus strains were determined. Proteolytic, lipolytic and tannase activities were identified in media after the bioremediation process. These enzymes can have application in laundry, since proteases and lipases are the key enzymatic constituents in detergent formulations to remove fatty and proteinaceous food stains (Grbavčić et al., 2011). Fig. 5a-c depict enzyme activities (U/L) in the three media fermented by A. ibericus, A. uvarum and A. niger. As it can be seen, the maximum proteolytic activity was obtained after bioremediation of OMW:VS by $A$. uvarum $(3700 \pm 124.3 \mathrm{U} / \mathrm{L})$. The higher content of protein in VS may have improved proteases production by the three strains. A. uvarum showed specificity to produce proteases but low concentration of lipases and tannases were produced. A. niger is known to produce proteases; however, the production of proteases by $A$. uvarum and $A$. ibericus is not documented. In other works, with similar proteolytic activity analysis, protease production by A. niger in SSF was $5.27 \mathrm{U} / \mathrm{mL}$ (Couri et al., 2000), while Bacillus subtilis achieved $12 \mathrm{U} / \mathrm{mL}$ in submerged fermentation with synthetic medium (Soares et al., 2005). The maximum lipase activity (1253.7 U/L \pm 161.2 ) was obtained by $A$. ibericus in fermentations with undiluted OMW. Except for A. uvarum, the highest lipase activity was observed in this medium, probably due to its higher lipids content, which act as inducer for the production of lipases. A. ibericus had already shown its ability to produce lipases, in OMW supplemented with mineral nutrients, a lipase activity of $2927.0 \mathrm{U} /$ L was achieved in bioreactor batch cultures (Abrunhosa et al., 2012).

A low tannase activity was detected with all three strains; however, A. niger was clearly the best producer. Media with OMW and mixtures of OMW and VS were suitable for the production of tannases, A. niger produced $284.4 \pm 12.1$ and $137.1 \pm 3.7 \mathrm{U} / \mathrm{L}$, respectively. These media showed a higher content in PC which could have induced the tannase production (Aissam et al., 2005). Despite the higher content of PC of OMW (6.2 g/L) in this study, $A$. niger was not inhibited and produced tannase during the bioremediation process. Aissam et al. (2005) also studied tannase 

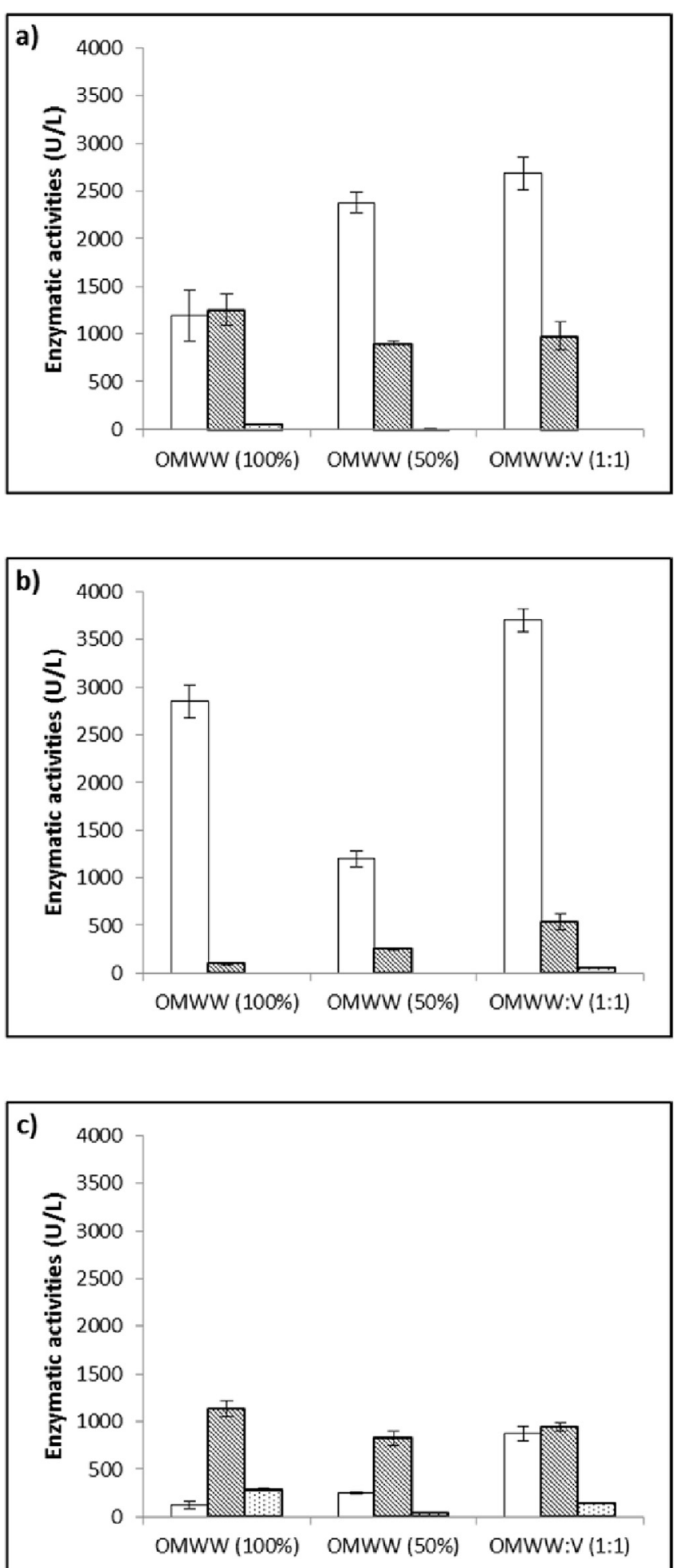

Fig. 5. Protease (clear), lipase (striped) and tannase (dotted) activities detected in effluents after the bioremediation with (a) A. ibericus MUM 03.49, (b) A. uvarum 01UAs128 and (c) A. niger MUM 03.58.

production by $A$. niger on four-fold diluted OMW and reported activities between 370 and $650 \mathrm{U} / \mathrm{L}$. Results were slightly higher; however, in this study, OMW was not diluted and was not supplemented with nutrients.

\section{Conclusions}

Three Aspergillus strains, namely A. niger MUM03.58, A. uvarum 01UAs128 and A. ibericus MUM 03.49, were selected among different strains in a screening process conducted in Petri disks, to reduce $\mathrm{PC}, \mathrm{COD}$ and colour of OMW. The best results were achieved in bioremediation processes using mixtures of OMW and VS, in the proportion $1: 1(\mathrm{v} / \mathrm{v})$, particularly when using the strain $A$. uvarum. Consequently, a positive effect can be inferred from mixing OMW and VS to reduce toxic compounds of effluents.

Moreover, the bioremediation processes of these effluents allowed the simultaneous production of enzymes with industrial interest, as lipases, proteases and tannases. A. ibericus, A. uvarum and $A$. niger achieved the highest values of lipase, protease and tannase activities, respectively. A positive effect of mixture OMW and VS was also observed on proteases production.

\section{Acknowledgements}

José Manuel Salgado and Luís Abrunhosa was supported by the grant SFRH/BPD/84440/2012 and SFRH/BPD/43922/2008 respectively, from Fundação para a Ciência e Tecnologia - FCT, Portugal. Authors thank Fundação para a Ciência e a Tecnologia (FCT) for financial support through the project FCT Pest-OE/EQB/LA0023/ 2011. Also, authors thank the Project "BioInd - Biotechnology and Bioengineering for improved Industrial and Agro-Food processes, REF. NORTE-07-0124-FEDER-000028" Co-funded by the Programa Operacional Regional do Norte (ON.2 - O Novo Norte), QREN, FEDER.

\section{References}

Abrunhosa, L., Oliveira, F., Dantas, D., Gonçalves, C., Belo, I., 2012. Lipase production by Aspergillus ibericus using olive mill wastewater. Bioprocess Biosyst. Eng. 36, 285-291.

Aissam, H., Errachidi, F., Penninckx, M.J., Merzouki, M., Benlemlih, M., 2005. Production of tannase by Aspergillus niger HA37 growing on tannic acid and Olive Mill Waste Waters. World J. Microb. Biotechnol. 21, 609-614.

Aissam, H., Penninckx, M.J., Benlemlih, M., 2007. Reduction of phenolics content and COD in olive oil mill wastewaters by indigenous yeasts and fungi. World J. Microb. Biotechnol. 23, 1203-1208.

Aouidi, F., Gannoun, H., Ben Othman, N., Ayed, L., Hamdi, M., 2009. Improvement of fermentative decolorization of olive mill wastewater by Lactobacillus paracasei by cheese whey's addition. Process Biochem. 44, 597-601.

Beltrán, F.J., García-Araya, J.F., Alvarez, P.M., 1999. Wine distillery wastewater degradation. Oxidative treatment using ozone and its effect on the wastewater biodegradability. J. Agric. Food Chem. 47, 3911-3918.

Bradford, M.M., 1976. A rapid and sensitive method for the quantitation of microgram quantities of protein utilizing the principle dye binding. Anal. Biochem. $72,248-254$.

Charney, J., Tomarelli, M., 1947. A colorimetric method for the determination of the proteolytic activity of duodenal juice. J. Biol. Chem. 171, 501-505.

Couri, S., Terzi, C., Saavedra, G.A., Pereira, S., Carlos, A., 2000. Hydrolytic enzyme production in solid-state fermentation by Aspergillus niger 3T5B8. Process Biochem. 36, 255-261.

D'Annibale, A., Ricci, M., Quaratino, D., Federici, F., Fenice, M., 2004. Panus tigrinus efficiently removes phenols, color and organic load from olive-mill wastewater Res. Microbiol. 155, 596-603.

España-Gamboa, E., Mijangos-Cortes, J., Barahona-Perez, L., DominguezMaldonado, J., Hernández-Zarate, G., Alzate-Gaviria, L., 2011. Vinasses: characterization and treatments. Waste Manage. Res. 29, 1235-1250.

España-Gamboa, E.I., Mijangos-Cortés, J.O., Hernández-Zárate, G., Maldonado, J.A.D. Alzate-Gaviria, L.M., 2012. Methane production by treating vinasses from hydrous ethanol using a modified UASB reactor. Biotech. Biofuels 82, 1-9.

Garcia-Garcia, I., Jiménez-Peña, P.R., Venceslada-Bonilla, J.L., Martín-Martín, A. Martín-Santos, M.A., Ramos-Gómez, E., 2000. Removal of phenol compounds from olive mill wastewater using Phanerochaete chrysosporium, Aspergillus niger, Aspergillus terreus. Process Biochem. 35, 751-758.

Garrido-Hoyos, S.E., Martinez-Nieto, L., Camacho-Rubio, F., Ramos-Cormenzana, A. 2002. Kinetics of aerobic treatment of olive-mill wastewater (OMW) with Aspergillus terreus. Process Biochem. 37, 1169-1176.

Gomes, N., Gonçalves, C., García-Román, M., Teixeira, J.A., Belo, I., 2011. Optimization of a colorimetric assay for yeast lipase activity in complex systems. Anal. Method 3, 1008-1013.

Gonçalves, C., Lopes, M., Ferreira, J.P., Belo, I., 2009. Biological treatment of olive mill 
wastewater by non-conventional yeasts. Bioresour. Technol. 100, 3759-3763.

Grbavčić, S., Bezbradica, D., Izrael-Živković, L., Avramović, N., Milosavić, N., Karadžić, I., Knežević-Jugović, Z., 2011. Production of lipase and protease from an indigenous Pseudomonas aeruginosa strain and their evaluation as detergent additives: compatibility study with detergent ingredients and washing performance. Bioresour. Technol. 102, 11226-11233.

Hamdi, M., 1993. Thermoacidic precipitation of darkly coloured polyphenols of olive mill wastewaters. Environ. Technol. 14, 495-500.

Lamarino, G. Rao, M.A. Gianfreda, L, 2009. Dephenolization and detoxification of olive-mill wastewater (OMW) by purified biotic and abiotic oxidative catalysts. Chemosphere 74, 216-223.

Jarboui, R., Magdich, S., Ayadi, R.J., Gargouri, A., Gharsallah, N., Ammar, E., 2013. Aspergillus niger P6 and Rhodotorula mucilaginosa $\mathrm{CH} 4$ used for olive mill wastewater (OMW) biological treatment in single pure and successive cultures. Environ. Technol. 34, 629-636.

Khan, R., Fulekar, P.B.M.H., 2013. Microbial decolorization and degradation of synthetic dyes: a review. Rev. Environ. Sci. Biotechnol. 12, 75-97.

Khatib, A., Aqra, F., Yaghi, N., Subuh, Y., Hayeek, B., Musa, M., Basheer, S., Sabbah, I., 2009. Reducing the environmental impact of olive mill wastewater. Am. J. Environ. Sci. 5, 1-6.

Lakhtar, H., Ismaili-Alaoui, M., Philippoussis, A., 2010. Screening of strains of Lentinula edodes grown on model olive mill wastewater in solid and liquid state culture for polyphenol biodegradation. Int. Biodeter. Biodegr. 64, 167-172.

Lanciotti, R., Gianotti, A., Baldi, D., Angrisani, R., Suzzi, G., Mastrocola, D., Guerzoni, M.E., 2005. Use of Yarrowia lipolytica strains for the treatment of olive mill wastewater. Bioresour. Technol. 96, 317-322.

Mann, J., Markham, J.L., Peiris, P., Nair, N., Holford, P., 2010. Screening and selection of fungi for bioremediation of olive mill wastewater. World J. Microb. Biotechnol. 26, 567-571.

McNamara, C.J., Anastasiou, C.C., O'Flaherty, V., Mitchell, R., 2008. Bioremediation of olive mill wastewater. Int. Biodeter. Biodegr. 61, 127-134.

Mekki, A., Dhouib, A., Sayadi, S., 2007. Polyphenols dynamics and phytotoxicity in a soil amended by olive mill wastewaters. J. Environ. Manag. 84 (2), 134-140.

Nitayavardhana, S. Khanal, S.K. 2010. Innovative biorefinery concept for sugarbased ethanol industries: production of protein-rich fungal biomass on vinasse as an aquaculture feed ingredient. Bioresour. Technol. 101, 9078-9085.

Ntougias, S., Baldrian, P., Ehaliotis, C., Nerud, F., Antoniou, T., Merhautová, V. Zervakis, G.I., 2012. Biodegradation and detoxification of olive mill wastewater by selected strains of the mushroom genera ganoderma and pleurotus. Chemosphere 88, 620-626.

Öngen, G., Güngör, G., Kanberoglu, B., 2007. Decolourisation and dephenolisation potential of selected Aspergillus section Nigri strains - Aspergillus tubingensis in olive mill wastewater. World J. Microb. Biotechnol. 23, 519-524.

Padovani, G., Pintucci, C., Carlozzi, P., 2013. Dephenolization of stored olive-mil wastewater, using four different adsorbing matrices to attain a low-cost feedstock for hydrogen photo-production. Bioresour. Technol. 138, 172-179.

Paradelo, R., Moldes, A.B., Barral, M.T., 2010. Utilization of a factorial design to study the composting of hydrolyzed grape marc and vinification lees. J. Agr. Food
Chem. 58, 3085-3089

Paraskeva, P., Diamadopoulos, E., 2006. Technologies for olive mill wastewater (OMW) treatment: a review. J. Chem. Technol. Biotechnol. 81, 1475-1485.

Perrone, G., Varga, J., Susca, A., Frisvad, J.C., Stea, G., Kocsubé, S., Tóth, B., Kozakiewicz, Z., Samson, R.A., 2008. Aspergillus uvarum sp. nov., an uniseriate black Aspergillus species isolated from grapes in Europe. Int. J. Syst. Evol. Microbiol. 58, 1032-1039.

Rytwo, G., Lavi, R., Rytwo, Y., Monchase, H., Dultz, S., König, T., 2013. Clarification of olive mill and winery wastewater by means of clay-polymer nanocomposites. Sci. Total Environ. 442, 134-142.

Salgado, J.M., Rodríguez, N., Cortés, S., Domínguez, J.M., 2009. Development of costeffective media to increase the economic potential for larger-scale bioproduction of natural food additives by Lactobacillus rhamnosus, Debaryomyces hansenii, and Aspergillus niger. J. Agric. Food Chem. 57, 10414-10428.

Salgado, J.M., Carballo, E.M., Max, B., Domínguez, J.M., 2010. Characterization of vinasses from five certified brands of origin $(\mathrm{CBO})$ and use as economic nutrient for the xylitol production by debaryomyces hansenii. Bioresour. Technol. 101, 2379-2388.

Salgado, J.M., Abrunhosa, L., Venâncio, A., Domínguez, J.M., Belo, I., 2014. Screening of winery and olive mill wastes for lignocellulolytic enzyme production from Aspergillus species by solid-state fermentation. Biomass Convers. Bioref. 4, 201-209.

Samson, R.A., Noonim, P., Meijer, M., Houbraken, J., Frisvad, J.C., Varga, J., 2007. Diagnostic tools to identify black Aspergilli. Stud. Mycol. 59, 129-146.

Sayadi, S., Ellouz, R., 1995. Roles of lignin peroxidase and manganese peroxidase from Phanerochaete chrysosporium in the decolorization of olive mill wastewaters. Appl. Environ. Microbiol. 61, 1098-1103.

Serra, R., Cabañes, F.J., Perrone, G., Castellá, G., Venâncio, A., Mulè, G., Kozakiewicz, Z., 2006. Aspergillus ibericus: a new species of section Nigri isolated from grapes. Mycologia 98, 295-306.

Sharma, S., Bhat, T.K., Dawra, R.K., Station, R., 1999. Isolation, purification and properties of tannase from Aspergillus niger van Tieghem. World J. Microb. Biotechnol. 15, 673-677.

Sierra, J. Martí, E. Garau, M.A. Cruañas, R., 2007. Effects of the agronomic use of olive oil mill wastewater: field experiment. Sci. Total Environ. 378, 90-94.

Soares, V.F., Castilho, L.R., Bon, E.P.S., Freire, D.M.G., 2005. High-yield Bacillus subtilis protease production by solid-state fermentation. Appl. Biochem. Biotechnol. $121-124,311-319$

Strong, P.J., 2009. Fungal remediation of Amarula distillery wastewater. World J. Microb. Biotechnol. 26, 133-144.

Vlyssides, A., Barampouti, E.M., Mai, S., Stamatoglou, A., Tsimas, E., 2010. Alternative biological systems for the treatment of vinasse from wine. Water Sci. Technol. 62, 2899-2904.

Yesilada, Ö., Sik, S., Sam, M., 1999. Treatment of olive oil mill wastewater with fungi. Turk. J. Biol. 23, 231-240.

Zirehpour, A., Rahimpour, A., Jahanshahi, M., Peyravi, M., 2014. Mixed matrix membrane application for olive oil wastewater treatment: process optimization based on taguchi design method. J. Environ. Manag. 132, 113-120. 